\title{
Non-episodic angioedema associated with eosinophilia
}

\author{
Kiyoshi Shikino, ${ }^{1}$ Yuta Hirose, ${ }^{1}$ Seitaro Nakagawa, ${ }^{2}$ Masatomi Ikusaka ${ }^{1}$
}

${ }^{1}$ Department of General Medicine, Chiba University Hospital, Chiba, Chiba, Japan ${ }^{2}$ Department of Dermatology, Chiba University Hospital, Chiba City, Chiba, Japan

\section{Correspondence to Dr Kiyoshi Shikino, kshikino@gmail.com}

Accepted 30 August 2016
CrossMark

To cite: Shikino K, Hirose Y,
Nakagawa S, et al. BMJ
Case Rep Published online:
[please include Day Month
Year] doi:10.1136/bcr-2016-
217428

\section{DESCRIPTION}

A 26-year-old woman presented with a 1-week history of peripheral oedema, fever and polyarthralgia. Physical examination revealed symmetrical nonpitting oedema of her hands and legs (figure 1). Her medical history was unremarkable. Laboratory findings showed blood eosinophilia $(3800 / \mu \mathrm{L})$. The serum IgM level was within normal. Skin histopathology revealed slight interstitial oedema, dilated venous vessels with endothelial swelling and inflammatory cells extending into the subcutaneous tissue (figure 2). Her condition was diagnosed as non-episodic angioedema with eosinophilia (NEAE). Her symptoms quickly improved with prednisolone $(15 \mathrm{mg} /$ day $)$. After tapering off of prednisolone, she has been recurrence-free for 2 years.

Angioedema with eosinophilia is classified as episodic angioedema with eosinophilia (EAE) or NEAE. EAE is characterised by recurrent episodes of angioedema, arthralgia and fever with a markedly high peripheral blood eosinophil count and high serum IgM level. NEAE is characterised by a single episode of persistent oedema of the extremities, peripheral eosinophilia, lack of an increased serum IgM level and a less severe clinical course than EAE. ${ }^{1}$ NEAE generally affects young Asian women. ${ }^{1}$ NEAE is also characterised by the effectiveness of low-dose prednisone or spontaneous remission. $^{2}$ The differential diagnosis includes Drug Reaction with Eosinophila and Systemic Symptoms (DRESS) syndrome consisting of a severe rash, fever, lymphadenopathy, elevated liver enzymes and/or eosinophilia. ${ }^{3}$

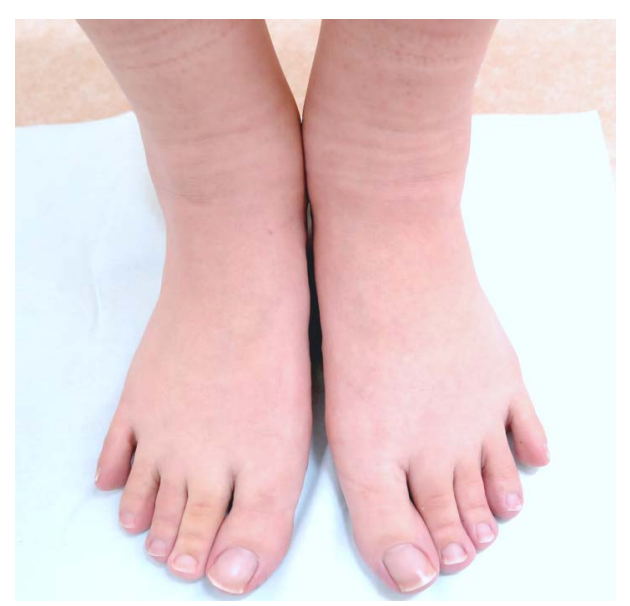

Figure 1 Symmetrical non-pitting oedema of her legs.

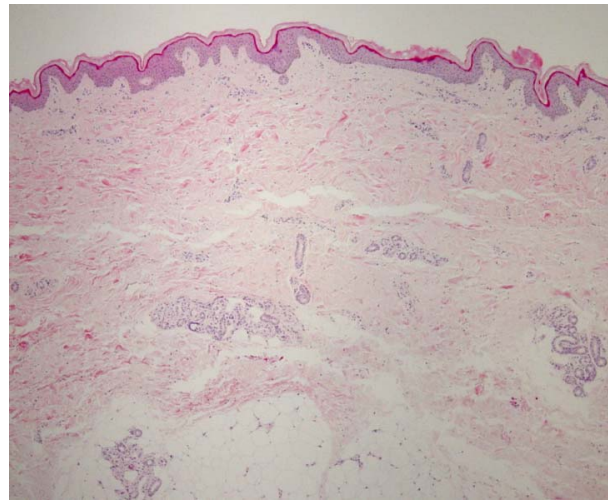

Figure 2 Histopathology of the skin showing slight interstitial oedema, dilated venous vessels with endothelial swelling and inflammatory cells extending into the subcutaneous tissue.

\section{Learning points}

- Angioedema with eosinophilia is classified as episodic angioedema with eosinophilia or non-episodic angioedema with eosinophilia (NEAE).

- NEAE is characterised by a single episode of persistent oedema of the extremities, peripheral eosinophilia, lack of an increased serum IgM level.

- NEAE is also characterised by the effectiveness of low-dose prednisone or spontaneous remission.

Twitter Follow Kiyoshi Shikino at @K

Contributors $\mathrm{KS}, \mathrm{YH}, \mathrm{SN}$ and $\mathrm{MI}$ were involved in managing the patient. KS wrote the first draft. SN made the pathology specimen. $\mathrm{Ml}$ edited the manuscript.

Competing interests None declared.

Patient consent Obtained.

Provenance and peer review Not commissioned; externally peer reviewed.

\section{REFERENCES}

1 Goto K, Ishizaki S, Tanese K, et al. Histological classification and differential diagnosis of nonepisodic angioedema with eosinophilia: a clinicopathologic study of 12 cases with literature review. Am J Dermatopathol 2016;38:124-30.

2 Chikama R, Hosokawa M, Miyazawa T, et al. Nonepisodic angioedema associated with eosinophilia: report of 4 cases and review of 33 young female patients reported in Japan. Dermatology 1998;197:321-5.

3 Spriet S, Banks TA. Drug reaction with eosinophilia and systemic symptoms syndrome. Allergy Asthma Proc 2015;36:501-5. 
Copyright 2016 BMJ Publishing Group. All rights reserved. For permission to reuse any of this content visit http://group.bmj.com/group/rights-licensing/permissions.

BMJ Case Report Fellows may re-use this article for personal use and teaching without any further permission.

Become a Fellow of BMJ Case Reports today and you can:

- Submit as many cases as you like

- Enjoy fast sympathetic peer review and rapid publication of accepted articles

- Access all the published articles

- Re-use any of the published material for personal use and teaching without further permission

For information on Institutional Fellowships contact consortiasales@bmjgroup.com

Visit casereports.bmj.com for more articles like this and to become a Fellow 